\title{
Evaluation of Tomato Lines against Septoria Leaf Spot under Field Conditions and Its Effect on Fruit Yield
}

\author{
Zishan Gul*, Mehboob Ahmed, Zaheer Ullah Khan, Bilal Khan, Mazhar Iqbal \\ Hazara Agriculture Research Station, Abbottabad, Pakistan \\ Email: "gul.zishan@gmail.com
}

Received 4 March 2016; accepted 7 April 2016; published 11 April 2016

Copyright (C) 2016 by authors and Scientific Research Publishing Inc.

This work is licensed under the Creative Commons Attribution International License (CC BY). http://creativecommons.org/licenses/by/4.0/

(c) (i) Open Access

\section{Abstract}

Field studies were conducted at Hazara Agriculture Research Station, Abbottabad to evaluate thirteen AVRDC lines along with one commercial check (Roma) for potential of fruit yield against septoria leaf spot during summer season 2014. The disease established itself by natural infection and disease severity was estimated with the help of 0 - 5 disease rating scale after 15 days interval from the onset of symptoms. The lines showed significant difference in \% septoria leaf spot infection. The disease severity \% increased up to $100 \%$ in line AVT01314 whereas the lowest \% severity was recorded in AVTO1173 which showed the highest yield (468.1 g) with average fruit weight $122.22 \mathrm{~g}$ while the significantly lowest mean yield/plant ( $35.05 \mathrm{~g})$ was calculated in line AVTO1314 with fruit weight $47.92 \mathrm{~g}$. It was concluded that the line AVT01173 could be useful in genetic programs for incorporating resistant genes in local tomato germplasm against septoria leaf spot disease.

\section{Keywords}

Tomato, Septoria Leaf Spot, Disease Severity, Fruit Yield

\section{Introduction}

Tomato (Lycopersicon esculentum Mill.) is the second most important world consumable vegetable after potato, ranks first among the processing crops [1] and belongs to Solanaceae family [2]. It is also the second major vegetable produced in Pakistan [3]. Some of the important varieties of tomato grown in Pakistan are Roma, Money

\footnotetext{
${ }^{*}$ Corresponding author.
}

How to cite this paper: Gul, Z., Ahmed, M., Khan, Z.U., Khan, B. and Iqbal, M. (2016) Evaluation of Tomato Lines against Septoria Leaf Spot under Field Conditions and Its Effect on Fruit Yield. Agricultural Sciences, 7, 181-186. 
maker, Nagina, Pakit, Feston, Peelo, Cherry, Nemadina, Eva T-89, T-10, Red Top, Marglobe and Cun Dayri [4]. Tomato is susceptible to over 200 diseases caused by pathogenic fungi, bacteria, viruses and nematodes [5]. Among fungal diseases Septoria leaf spot (Septoria lycopersici Speg.) is one of the most devastating foliar diseases in humid regions, particularly during the periods of rainfall, frequent dew or overhead irrigation [6].

Parker et al. (2000) [7] reported that tomato plants were highly susceptible to disease attack in the field at all stages of their growth and could be highly destructive in wet and warm climate. Although the causal fungus (Septoria lycopersici) will not directly infect fruits, losses are due to defoliation leading to fruit maturity failure and sunscald injury [8].

The disease first appears as small, water-soaked spots that soon become circular and about $1 / 8$ inch in diameter with grayish white centers and dark edges, which is the most characteristic symptom of this disease. Under favorable environmental conditions, fungal fruiting bodies appear as tiny black specks in the centers of the spots. Heavily infected leaves turn yellow, wither, and eventually fall off. Infection initiates at lower leaves first, and then progresses upward if rainy weather persists [9].

High humidity and moderate air temperature during the crop season favour the disease development causing pre-mature defoliation resulting in considerable yield losses [10]. Lack of information about septoria leaf spot in locally grown tomato cultivars of Pakistan and especially District Abbottabad, this study was conducted to screen and select the tomato lines which showed less or no susceptibility to septoria leaf spot and its effect on tomato yield in order to select a resistant tomato germplasm against this important disease for future variety development.

\section{Materials and Methods}

Thirteen exotic AVRDC (Asian vegetable research and development centre) lines selected on the basis of fruit weight (>50 g) and fruit colour (bright red) were sown in pots in April 2014 along with a locally grown tomato variety Roma (medium pear shaped fruit having red colour) as check variety, at Hazara Agriculture Research Station Abbottabad to evaluate the performance of genotypes for resistance to septoria leaf spot disease and its effect on tomato yield under local environmental conditions of District Abbottabd, Pakistan. The lines were transplanted in June 2014 in a randomized complete block design (RCBD) with each line replicated 2 times having plants spaced $40 \mathrm{~cm}$ apart. The field soil was loamy soil with well composted organic fertilizer (Farm Yard Manure) was applied at the time of land preparation. The plants were grown under rainfed conditions after transplantation in the field. Response of lines under natural environmental condition was noted against septoria leaf spot. Data on the disease severity was recorded on $15^{\text {th }}$ August, $1^{\text {st }}$ September and on $15^{\text {th }}$ September 2014, using 0 - 5 disease rating scale [11] as shown in Table 1. Plants in this trial were not sprayed with any fungicide.

Sampling was done for isolation, identification and confirmation of Septoria leaf spot in the laboratory. Diseased leaf samples from upper, middle and lower plant portion were collected randomly. Microscopic slides were made directly from field samples and also the samples were cultured aseptically on PDA (Potato Dextrose Agar) media and incubated at $25^{\circ} \mathrm{C}$ for 1 week. Fungus was identified on the basis of morphological characteristics using mycological keys [12] [13]. Average temperature (min-max), number of rainy days, \% humidity for the months of August and September were also recorded (Table 2).

Data were collected on \% disease severity, fruit weight, No. of fruits/plant and per-plant yield. All the data was analyzed by using Statistix 8.1 software and LSD tests were performed for significance of results.

Table 1. Disease rating scale for the assessment of Septoria leaf blight of tomato.

\begin{tabular}{ccc}
\hline Scale & \% Disease severity & Description \\
\hline 0 & 0.0 & $0-5$ per cent leaf area infected and covered by spots \\
1 & $0 \%-5 \%$ & $6-20$ percent leaf area infected and covered by spots \\
2 & $6 \%-20 \%$ & $21-40$ per cent leaf area infected and covered by spots \\
4 & $21 \%-40 \%$ & $41-70$ per cent leaf area infected and covered by spots \\
5 & $41 \%-70 \%$ & $>71$ per cent leaf area infected and covered by spots
\end{tabular}




\section{Results}

\section{1. \% Disease Severity}

The data regarding first observation dated $15^{\text {th }}$ August 2014 on percent septoria leaf spot disease severity (Table 3 ) showed that there is significant difference among the lines for disease severity i.e. $p<0.05$. The linesAVTO1004 and AVTO9001 showed significantly highest mean percentage of disease severity i.e. $52.5 \%$ and 50\%, respectively, while lines AVTO1173, AVTO1008 and AVTO1003 showed no or very less disease severity percentage i.e. $0 \%, 2.5 \%$ and $8 \%$ respectively.

The data regarding second observation on $1^{\text {st }}$ September 2014 showed that the $\%$ disease severity increases in almost all the evaluated lines. The line AVTO1314 showed the highest \% disease severity (90\%) followed by AVTO9001 (80\%). The lowest septoria leaf spot severity percentage was recorded in lines AVTO1173 and AVTO1219 (8\% and 17.5\%) respectively (Table 3).

The lines showed significant difference in \% septoria leaf spot. The disease severity \% increased up to $100 \%$ in line AVTO1314 whereas the lowest \% severity was 10\% recorded in AVTO1173 (Table 3).

The common feature of the septoria infected plant samples collected from the field was the presence of varying degrees of leaf spots and necrosis. Extensive portions of the leaves in some lines were necrotic and a number of the leaves were completely destroyed (Figure 1). The pathogen was isolated from the infected leaves samples and cultured on PDA media to confirm septoria leaf spot disease. Septoria lycopersici spores were seen and identified in microscopic slides on the basis of morphological charecters and micrometery. The spores (conidia) were filiform, sub-straight to slightly curved, septate having 4-8 septa. The conidial size ranged from $70-150 \mathrm{x}$ 2 - $3 \mu \mathrm{m}$ (Figure 2).

Table 2. Average weather parameters recorded during study period (2014) in the experimental field.

\begin{tabular}{cccc}
\hline Months & Average temperature (min-max) ${ }^{\circ} \mathrm{C}$ & Average number of rainy days & Average \% humidity \\
\hline August & $22-30$ & 10 & $80 \%$ \\
September & $19-29$ & 7 & $78 \%$ \\
\hline
\end{tabular}

Table 3. AVRDC tomato lines showing different disease severity under natural field conditions during the year 2014.

\begin{tabular}{|c|c|c|c|c|}
\hline \multirow{2}{*}{ S. No } & \multirow{2}{*}{ AVRDC tomato lines } & \multicolumn{3}{|c|}{ \% Disease severity } \\
\hline & & $15^{\text {th }}$ August & $1^{\text {st }}$ September & $15^{\text {th }}$ September \\
\hline 1 & AVTO1173 & $0 \mathrm{~g}$ & $8 \mathrm{~g}$ & $10 \mathrm{f}$ \\
\hline 2 & AVTO1003 & $8 \mathrm{fg}$ & $20 \mathrm{fg}$ & $25 \mathrm{e}$ \\
\hline 3 & AVTO1315 & $30 \mathrm{~cd}$ & $45 \mathrm{bcd}$ & $77.50 \mathrm{c}$ \\
\hline 4 & AVTO1004 & $52.5 \mathrm{a}$ & 75 a & $80 \mathrm{bc}$ \\
\hline 5 & AVTO9601 & $30 \mathrm{~cd}$ & 37.5 cde & $55 \mathrm{~d}$ \\
\hline 6 & AVTO1311 & $30 \mathrm{~cd}$ & $57.5 \mathrm{~b}$ & $70 \mathrm{c}$ \\
\hline 7 & AVTO1314 & $45 \mathrm{ab}$ & 90 a & $100 \mathrm{a}$ \\
\hline 8 & AVTO9001 & $50 \mathrm{a}$ & 80 a & $92.50 a b$ \\
\hline 9 & AVTO0201 & $27.5 \mathrm{~cd}$ & $50 \mathrm{bc}$ & $80 \mathrm{bc}$ \\
\hline 10 & AVTO0101 & $12.5 \mathrm{ef}$ & 32.5 def & $55 \mathrm{~d}$ \\
\hline 11 & AVTO1008 & $2.5 \mathrm{fg}$ & $27.5 \mathrm{ef}$ & $27.5 \mathrm{e}$ \\
\hline 12 & AVTO1002 & 20 de & 52.5 bc & $72.50 \mathrm{c}$ \\
\hline 13 & AVTO1219 & 12.5 ef & $17.5 \mathrm{fg}$ & 35 e \\
\hline 14 & ROMA & $37.5 \mathrm{bc}$ & $45 \mathrm{bcd}$ & $55 \mathrm{~d}$ \\
\hline
\end{tabular}

Mean values followed by different letters are significant at probability level 0.05 in a column. 

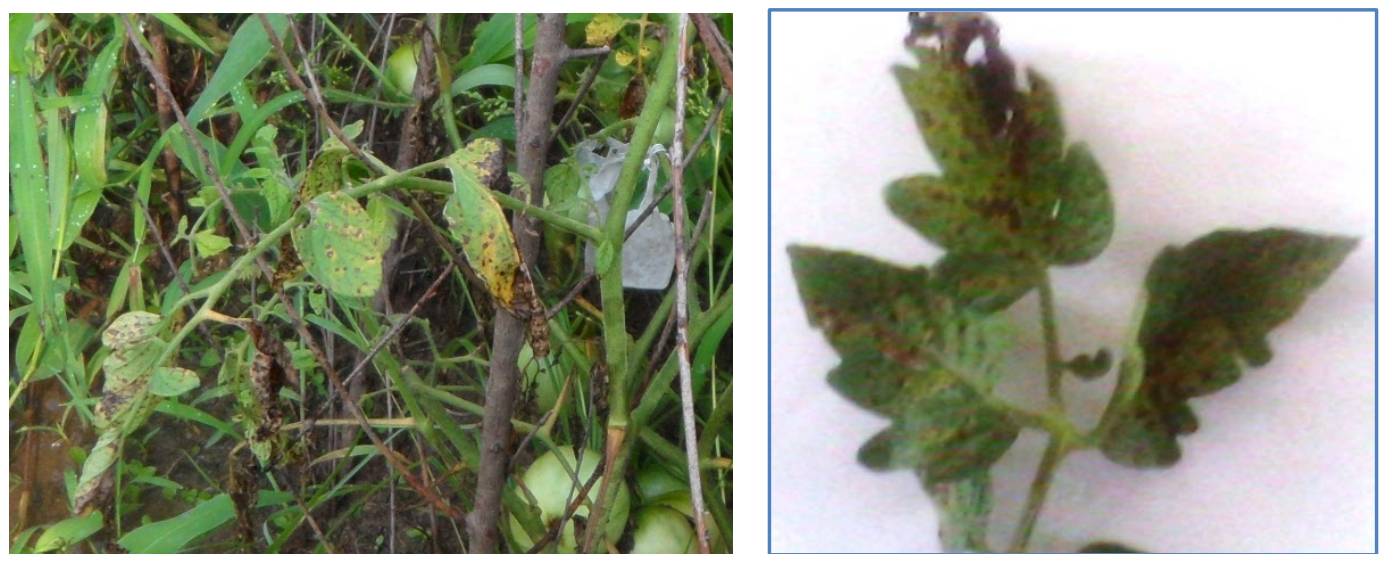

Figure 1. Septoria leaf spot infection on tomato plants in the field.
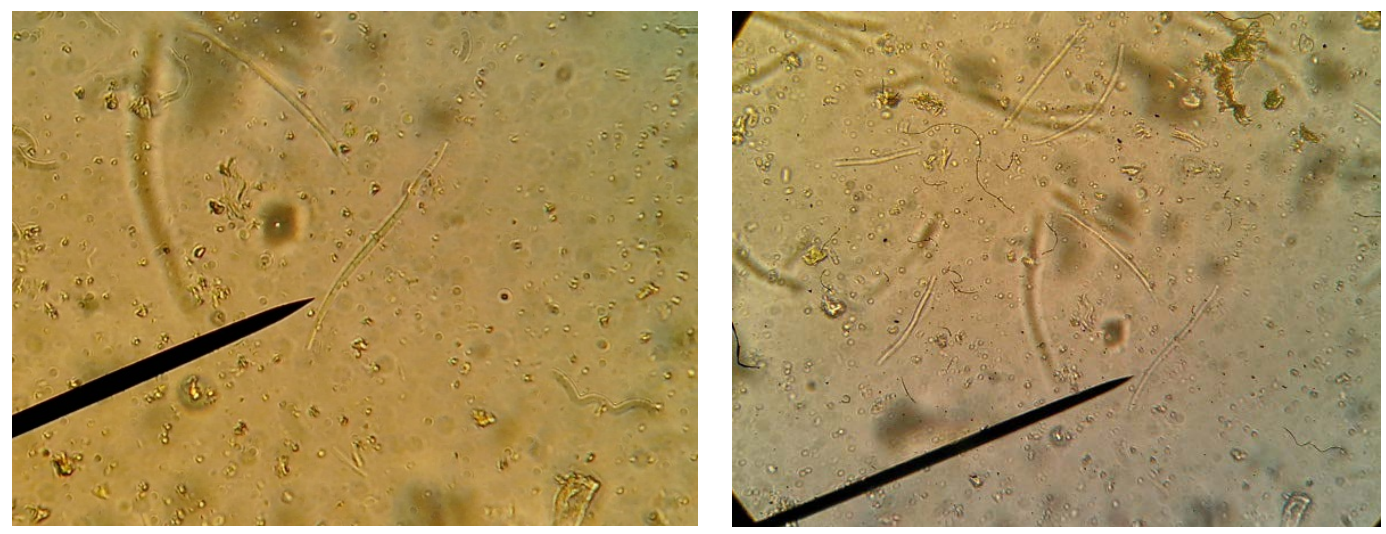

Figure 2. Septoria lycopersicae spores produced in pure culture on PDA after incubation at $25^{\circ} \mathrm{C}$ for 10 days (400X).

\subsection{Fruit Weight}

Analyzed data for fruit weight (grams) showed that there is significant difference among all the lines at $\mathrm{p}<0.05$ (Table 4). The line AVTO1173 showed the highest value for average fruit weight in grams (122.22) while the lowest value for fruits weight was shown by the line AVTO1003 i.e. $42.25 \mathrm{~g}$ and line AVTO1314 (47.92 g).

\subsection{No. of Fruits per Plant}

Analyzed data for the parameter average number of fruits per plant showed non-significant difference among the lines at $\mathrm{p}>0.05$. The highest value of no of fruits/plant was shown by the lines AVTO1173 and AVTO1003 i.e. mean 7.5 fruits/plant while the lowest value was shown by the line AVTO1314 i.e. mean 1.5 fruit/plant (Table 4).

\subsection{Yield per Plant}

Highly significant difference $\mathrm{p}<0.05$ was found among all the lines for yield/plant in grams (Table 4). The line AVTO1173 showed highest value for the yield parameter i.e. 468.1 grams while the significantly lowest mean value of yield/plant was calculated in line AVTO1314 i.e. 35.05 grams.

\section{Discussion}

The results showed that the presence and \% severity of septoria leaf spot disease of tomato in district Abbottabad, Pakistan was high and plant defoliation was encountered in the field. The septoria infected plant samples showed leaf necrosis and a number of the leaves were completely destroyed. This may be due to presence of high humidity and warm environmental conditions as repeated rainfalls occurred during the month of August 
Table 4. Relative performance of AVRDC tomato lines evaluated at Hazara agriculture research station, Abbottabad.

\begin{tabular}{|c|c|c|c|c|}
\hline S.No & AVRDC tomato lines & Fruit weight/plant (g) & Fruit number/plant & Yield/plant (g) \\
\hline 1 & AVTO1173 & $122.22 \mathrm{a}$ & $7.500 \mathrm{a}$ & 468.11 a \\
\hline 2 & AVTO1003 & $42.25 \mathrm{~d}$ & $7.500 \mathrm{a}$ & $333.13 \mathrm{abc}$ \\
\hline 3 & AVTO1315 & $61.88 \mathrm{bcd}$ & 3.375 bc & 102.25 ef \\
\hline 4 & AVTO1004 & $57.91 \mathrm{~cd}$ & $4.750 \mathrm{ab}$ & 217.32 cde \\
\hline 5 & AVTO9601 & 122.18 a & $3.000 \mathrm{bc}$ & 288.81 bcd \\
\hline 6 & AVTO1311 & 80.50 abcd & $3.000 \mathrm{bc}$ & 222.15 cde \\
\hline 7 & AVTO1314 & $47.92 \mathrm{~cd}$ & $1.500 \mathrm{c}$ & $35.05 \mathrm{f}$ \\
\hline 8 & AVTO9001 & $54.20 \mathrm{~cd}$ & 2.775 bc & 166.76 def \\
\hline 9 & AVTO0201 & $62.00 \mathrm{bcd}$ & $4.000 \mathrm{abc}$ & 155.00 def \\
\hline 10 & AVTO0101 & $87.51 \mathrm{abc}$ & $3.625 \mathrm{bc}$ & 174.72 cdef \\
\hline 11 & AVTO1008 & 80.23 abcd & $5.830 \mathrm{ab}$ & $430.01 \mathrm{ab}$ \\
\hline 12 & AVTO1002 & 81.18 abcd & $2.8300 \mathrm{bc}$ & 173.59 cdef \\
\hline 13 & AVTO1219 & $104.00 \mathrm{ab}$ & $5.250 \mathrm{ab}$ & 294.39 bcd \\
\hline 14 & ROMA & $49.78 \mathrm{~cd}$ & $6.250 \mathrm{ab}$ & 230.55 cde \\
\hline
\end{tabular}

Mean values followed by different letters are significant at probability level 0.05 in a column.

(Table 2). The warm and humid environment persists during September therefore the disease progressed in those lines having less or no resistance causing up to 100\% infection. Sugha and Kumar (2000) [10] reported that rainfall caused splashing of septoria spores. Sufficient initial inoculum coupled with high humidity for 48 $60 \mathrm{~h}$ will result in severe development of disease. Marcinkowska (1977) [14] reported that an increase in inoculum load decreased the incubation period and accelerated the pace of disease development. Delahaut and Stevenson (2004) [4] reported that Septoria leaf spot (Septoria lycopersici Speg) was the most devastating diseases in humid regions, particularly during the periods of rainfall.

The results of the effects of septoria leaf spot on yield parameters of the tomato plants are presented in Table 4. Yield per tomato plant varied significantly $(\mathrm{P}<0.05)$ among the lines. However, the fruit number and fruit weight per plant of the tested lines recorded in this study were mainly as a result of their genetic background.

Based on the visual observations in the field, yield of marketable fruits per plant and disease severity percentage (Table 3 \& Table 4), the lines AVTO1173, AVTO1008, AVTO1003 and AVTO1219 show significantly less disease infection and greater yield while the local check variety ROMA shows comparatively slightly moderate infection. This may be due to presence of resistance in these lines against septoria infection that enable the plants to tolerate infection to a certain level without affecting yield as reported by Barksdale (1982) [15] who tested some tomato breeding lines against septoria leaf spot and found that disease increase on resistant lines was slow as compared to susceptible cultivars which showed severe defoliation.

Estimation of disease progress expressed as percent disease severity with time is based on the damage of total potential leaf area which shows a relationship between fruit yield and \% disease severity. The range of disease expression among lines may also be caused by slight differences in plant maturity characteristics and growth habit in terms of foliage canopy among lines. Septoria leaf spot did not significantly reduce yield of those lines where leaf damage expressed as \% disease severity was less than 35\% in September because at this time fruit ripening started. These lines could be useful as sources of materials for developing resistant variety against septoria disease in Pakistan and especially for Hazara division of Khyber Pakhtunkhwa province.

\section{Conclusion and Recommendation}

The lines AVTO1173, AVTO1008, AVTO1003 and AVTO1219 showed comparatively less septoria infection and higher yield. Therefore, these disease resistant lines need to be tested further on other locations to get more information on percent septoria infection in relation to yield in order to develop improved variety that has resistance against septoria leaf spot for the area like Abbottabad where heavy rainfall occurs and relative humidity is high. 


\section{Acknowledgements}

We gratefully thank the Asian Vegetable Research and Development Center (AVRDC), Taiwan for provision of tomato breeding lines.

\section{References}

[1] FAO (2008) Tomato Production Statistic. Food and Agriculture Organization of the United Nations, Rome.

[2] Saravanan, S., Thamburaj, S., Veeraragavathatham, D. and Subbiah, A. (2003) Effects of Seaweed Extract and Chlormequat on Growth and Fruit Yield of Tomato (Lycopersicon esculentum Mill.). Indian Journal of Agricultural Research, 37, 79-87.

[3] Mirza, I. (2007) Tomato Paste Plant to Be Set up at Killa Saifullah. http://www.pakissan.com/english/news/newsDetail.php?newsid=15041

[4] Burney, K. (1996) Collaborative Vegetable Research in South Asia. Proceedings of the Phase Final Workshop of South Asian Vegetable Research Network, Khatmandu, 23-28 January 1996, 383.

[5] Lukyanenko, A.N. (1991) Disease Resistance in Tomato. In: Kalloo, G., Ed., Genetic Improvement of Tomato, Vol. 14, Monographs on Theoretical and Applied Genetics, Springer, Berlin, 99-119. http://dx.doi.org/10.1007/978-3-642-84275-7_9

[6] Delahaut, K. and Stevenson, W. (2004) Tomato Disorders: Early Blight and Septoria Leaf Spot. A2606: R-0504, The University of Wisconsin, Madison.

[7] Parker, S.K., Nutter Jr., F.W. and Gleason, M.L. (2001) Directional Spread of Septoria Leaf Spot in Tomato Rows. Plant Disease, 81, 272-276. http://dx.doi.org/10.1094/PDIS.1997.81.3.272

[8] Watt, B.A. (2000) Septoria Leaf Spot of Tomato. University of Maine-Fact Sheet. http://www.pmo.umext.maine.edu/factsht/septum.htm

[9] Gleason, M.L. and Edmunds, B.A. (2006) Tomato Diseases and Disorders. University Extension PM 1266, Iowa State University, Ames.

[10] Sugha, S.K. and Kumar, S. (2000) Factors Affecting the Development of Septoria Leaf Spot of Tomato. Indian Phytopathology, 53, 178-180.

[11] Gondal, A.S., Ijaz, M., Riaz, K. and Khan, A.R. (2012) Effect of Different Doses of Fungicide (Mancozeb) against Alternaria Leaf Blight of Tomato in Tunnel. Journal of Plant Pathology \& Microbiology, 3, 125. http://dx.doi.org/10.4172/2157-7471.1000125

[12] Barnett, H.L. and Hunter, B.B. (1998) Illustrated Genera of Imperfect Fungi. 4th Edition, APS Press, St. Paul, 218 p.

[13] Shin, H.D., Sameva, E.F. and Kim, J.D. (2001) Morphometric Studies on the Genus Septoria in Korea (I). Mycobiology, 29, 145-153.

[14] Marcinkowska, P. (1977) Septoria Leaf Spot of Tomato. The Development of the Disease under Glass House and Field Conditions. Acta Agrobotanica, 30, 341-358. http://dx.doi.org/10.5586/aa.1977.026

[15] Barksdale, T.H. (1982) Control of an Epidemic of Septoria Leaf Spot of Tomato by Resistance. Plant Disease, 66, 239-240. http://dx.doi.org/10.1094/PD-66-239 